\title{
C/SiOC Composites by a Modified PIP Using Solid Polysiloxane: Fabrication, Microstructure and Mechanical Properties
}

\author{
WU Qing-Qing ${ }^{1,2}$, WANG Zhen ${ }^{1,3}$, DING Qi ${ }^{1,2,4}$, NI De-Wei ${ }^{1,3}$, KAN Yan-Mei ${ }^{1,3}$, DONG Shao-Ming ${ }^{1,5}$
}

(1. The State Key Lab of High Performance Ceramics and Superfine Microstructures, Shanghai Institute of Ceramics, Chinese Academy of Sciences, Shanghai 200050, China; 2. University of Chinese Academy of Sciences, Beijing 100049, China; 3. Structural Ceramics and Composites Engineering Research Center, Shanghai Institute of Ceramics, Chinese Academy of Sciences, Shanghai 200050, China; 4. ShanghaiTech University, Shanghai 201210, China; 5. Center of Materials Science and Optoelectronics Engineering, University of Chinese Academy of Sciences, Beijing 100049, China)

\begin{abstract}
A modified polymer infiltration and pyrolysis method (PIP) was developed to enhance the densification of $\mathrm{C} / \mathrm{SiOC}$ composites, using molten $\mathrm{MK}$ resin (polymethylsilsesquioxane) as precursor. Organic sulfonic acid was added as cross-linking agent to lower the curing temperature. The cross-linking mechanism and ceramization behavior of MK resin was studied. A high ceramic yield of about $85 \mathrm{wt} \%$ and low free carbon content below $3 \mathrm{wt} \%$ are achieved, with excellent high-temperature stability of the derived SiOC. The modified PIP approach presents a high densification efficiency. After only 8 PIP cycles, the final C/SiOC composites possess a density of about $1.81 \mathrm{~g} / \mathrm{cm}^{3}$. Compared with those composites fabricated by conventional PIP process, the C/SiOC composites prepared by modified PIP process show a much denser microstructure with much more improved densification efficiency. Bending strength of the as-fabricated $\mathrm{C} / \mathrm{SiOC}$ composites is of $(312 \pm 25) \mathrm{MPa}$, showing obvious non-brittle fracture behavior.
\end{abstract}

Key words: C/SiOC composite; high-efficient PIP; microstructure; cross-linking mechanism

Continuous fiber reinforced ceramic matrix composites (CFRCMCs) have been considered as excellent structure materials for the applications requiring low specific weight, high strength and toughness at elevated temperature ${ }^{[1-2]}$. Generally, several approaches can be used for the fabrication of CFRCMCs, such as chemical vapor infiltration (CVI), slurry infiltration (SI), and precursor infiltration and pyrolysis (PIP), etc. ${ }^{[3-4]}$. Among these methods, the PIP route is getting increasing attention in recent years, due to its advantages in low processing temperature, controllable ceramic compositions, suitable for large-scale components fabrication with complicated shapes and low $\operatorname{cost}^{[5-6]}$.

As a type of amorphous ceramic, SiOC can be considered as an anionic modification of silica glass in which $\mathrm{Si}-\mathrm{O}$ bonds are partially replaced by $\mathrm{Si}-\mathrm{C}$ bonds, and the other carbon atoms, free carbon, form graphene-like layers $^{[7]}$, which are expected to improve the thermal and mechanical properties for the applications at high temperatures ${ }^{[8-9]}$. Owing to the advantages such as excellent high temperature stability, oxidization resistance and low cost, polymer-derived silicon oxycarbides (SiOC) ceramics attract lots of attention being of CRFCMCs. As reported, $\mathrm{C} / \mathrm{SiOC}$ composites showed excellent mechanical performance, which was fabricated by using polysiloxane (PSO) as $\mathrm{SiOC}$ precursor ${ }^{[10]}$. In recent years, liquid hydrogen-containing PSO or polymethyl(phenyl)siloxane flake was used as precursor for SiOC. Their pyrolysates at $1000{ }^{\circ} \mathrm{C}$ have relatively high content of free carbon (about $26 \mathrm{wt} \%$ or even $29 \mathrm{wt} \%)^{[11-12]}$, which can easily react with $\mathrm{SiO}_{2}$ phase at high temperature, leading to high-temperature instability of composites. Among the common polysiloxanes, MK resin is a carbon-poor precursor for SiOC ceramic with carbon content of about $14 \mathrm{wt} \%$ and only about $8 \mathrm{wt} \%$ free carbon ${ }^{[13-14]}$, which makes $\mathrm{MK}$ resin a promising precursor for $\mathrm{C} / \mathrm{SiOC}$ composites.

In the present study, a modified PIP process with high efficiency was developed to fabricate $\mathrm{C} / \mathrm{SiOC}$ composites based on MK resin. The cross-linking and pyrolysis behavior of MK resin was optimized and the crosslinking mechanism was studied. The microstructures and mechanical properties of $\mathrm{C} / \mathrm{SiOC}$ composites fabricated through the modified PIP process were investigated. 


\section{Experimental}

A commercially available polysiloxane (MK resin, Wacker GmbH, Burghausen, Germany) was used as the precursor for SiOC matrix. As reported in literature ${ }^{[15-17]}$, MK resin in state of white powders, possesses ca. $2 \mathrm{~mol} \%$ of cross-linkable hydroxy and ethoxy groups with $\left[\mathrm{CH}_{3} \mathrm{SiO}_{1.5}\right]_{n}$ basic structure referred as polymethylsilsesquioxane. Its possible structure is depicted in Fig. $1^{[15]}$ To lower the curing temperature and shorten the curing period, organic sulfonic acid was chosen as crosslinking agent (henceforth referred as CLA).

MK resin was firstly compacted into a cylindroid tablet with a diameter of $10 \mathrm{~mm}$, to investigate its softening behavior. The photograph and the size of the tablet were recorded in situ as a function of temperature by a high temperature real-time observation and test system (TOMAC, FRAUNHOFER- GESELLSCHAFT, Germany) at a heating rate of $1{ }^{\circ} \mathrm{C} / \mathrm{min}$ in vacuum. The viscosity of $\mathrm{MK}$ resin at different temperatures and the dynamic modulus at $160{ }^{\circ} \mathrm{C}$ were measured by a rheometer (MCR301, Anton Paar $\mathrm{GmbH}$, Austria). In order to investigate the curing mechanism, the functional groups of PSO before and after cross-linking process were analyzed by a FT-IR spectroscopy (NICOLET 1s10, Thermo Scientific, America). To investigate ceramization behavior of MK resin, the thermogravimetric (TG) and differential thermal analysis (DTA) were performed with MK resin on a STA 449/F3 simultaneous thermal analyzer (Netzsch, Germany). The heating rate for DTA measurement was $10{ }^{\circ} \mathrm{C} / \mathrm{min}$ in flowing Ar. Content of oxygen and carbon atoms were analyzed by oxygen/ nitrogen detertminator (TC600C, LECO, America) and carbon/ sulfur detertminator (CS2000, ELTRA, Germany), respectively.

Three-dimensional needle-punched carbon fiber preforms fabricated with T700SC carbon fiber $(12 \mathrm{~K})$ were used as the reinforcement in this study. MK resin with different contents of CLA was cross-linked at $160{ }^{\circ} \mathrm{C}$ in vacuum and then pyrolyzed at $1000{ }^{\circ} \mathrm{C}$ in Ar atmosphere. A modified PIP process illustrated in Fig. 2 was performed to fabricate the $\mathrm{C} / \mathrm{SiOC}$ composites. Following this process, the composites with dense matrix can be achieved. In the modified PIP process, MK resin with

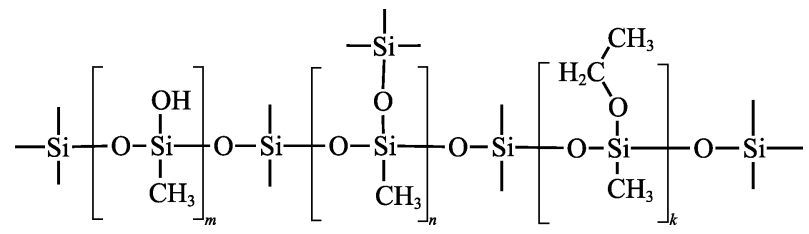

Fig. 1 Scheme of the possible structure of MK resin ${ }^{[15]}$
CLA was firstly heated to melt, and then was infiltrated into the fiber preform placed in a flexible container with aids of pressure difference between inside and outside of the flexible container. Secondly, the infiltrated preform was cured at $160{ }^{\circ} \mathrm{C}$ for $6 \mathrm{~h}$. Thirdly, the cured specimens were pyrolyzed at $1000{ }^{\circ} \mathrm{C}$ for $30 \mathrm{~min}$ at a heating rate of $5^{\circ} \mathrm{C} / \mathrm{min}$ in $\mathrm{Ar}$ atmosphere, and then cooled down to room temperature. PIP process was repeated for 8 times to get $\mathrm{C} / \mathrm{SiOC}$ composites with high densities. As a contrast, a conventional PIP process with ethanol solution of $\mathrm{MK}$ resin being used as precursor was utlized to fabricate $\mathrm{C} / \mathrm{SiOC}$ composites. To clearly distinguish between the two kinds of $\mathrm{C} / \mathrm{SiOC}$ composites, the $\mathrm{C} / \mathrm{SiOC}$ composites fabricated by the modified $\mathrm{PIP}$ process is henceforth referred as $\mathrm{M}-\mathrm{C} / \mathrm{SiOC}$ composites, and the $\mathrm{C} / \mathrm{SiOC}$ composites fabricated by the conventional PIP process is referred as $\mathrm{C}-\mathrm{C} / \mathrm{SiOC}$ composites.

The densities as well as open porosities of the $\mathrm{C} / \mathrm{SiC}$ composites were measured by Archimedes method with deionized water as the immersion medium. The bending strength of the final composites was characterized by three-point bending test (DDL20, Changchun Research Institute for Mechanical Science Co. Ltd, Changchun, China) with a span length of $50 \mathrm{~mm}$ and a crosshead speed of $0.5 \mathrm{~mm} / \mathrm{min}$. The dimensions of the specimens for three-point bending test were $60 \mathrm{~mm} \times 6 \mathrm{~mm} \times 4 \mathrm{~mm}$. Microstructures of composites were observed on both the fracture surfaces and polished cross-sections using a field-emission scanning electron microscope (Hitachi SU8220, Japan).

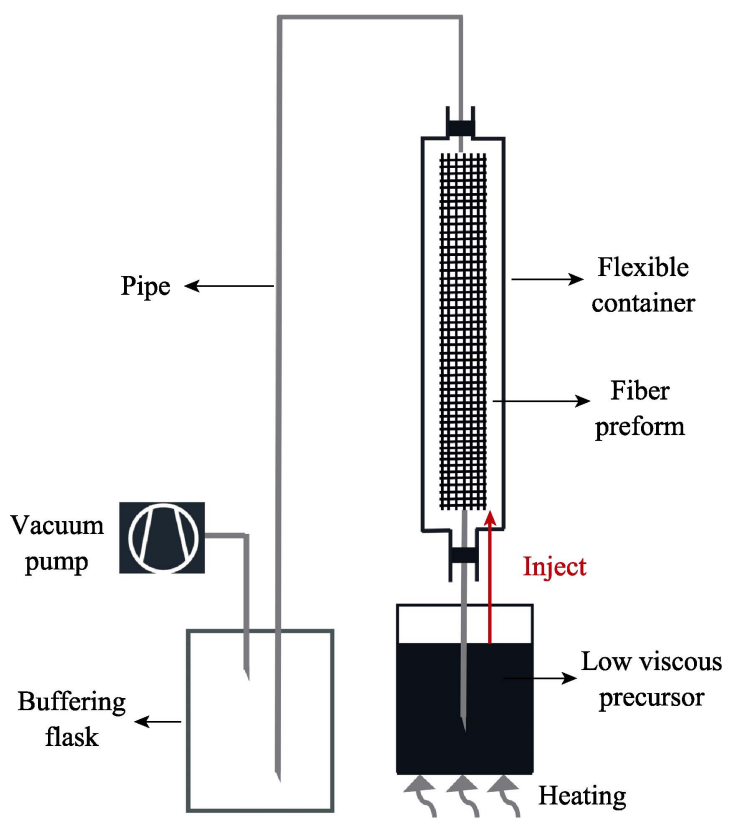

Fig. 2 Schematic diagram of the modified PIP process 


\section{Results and discussion}

\subsection{Viscosity-temperature characteristics of MK resin}

The viscosity of precursor is a key parameter for control of the PIP process. The high viscosity of precursor would lead to a poor fluidity during the impregnation process, while the excessively low viscosity would make the precursor easily flow out of the preforms during the crosslinking process ${ }^{[18]}$. Therefore, the viscosity of MK resin was investigated firstly as a function of temperature. Softening point was determined by the change of geometric size of the MK resin as shown in Fig. 3(a). It can be observed that there is no obvious deformation of $\mathrm{MK}$ resin at temperature below $55{ }^{\circ} \mathrm{C}$, while the right angle turned into round ones when the temperature was rising above $60{ }^{\circ} \mathrm{C}$. It reveals that the softening point of MK resin is in the range of 55-60 ${ }^{\circ} \mathrm{C}$. As shown in Fig. 3(b), it is clear that the viscosity of MK resin drops sharply at temperature higher than $110{ }^{\circ} \mathrm{C}$. The viscosities of MK resin are about $100 \mathrm{mPa} \cdot \mathrm{s}$ at $150{ }^{\circ} \mathrm{C}, 144 \mathrm{mPa} \cdot \mathrm{s}$ at $160{ }^{\circ} \mathrm{C}$ and $87 \mathrm{mPa} \cdot \mathrm{s}$ at $170{ }^{\circ} \mathrm{C}$, respectively.

\subsection{Curing and ceramization behavior of MK resin}

As a kind of thermoplastic polymer, MK resin begins to cross-link above $250{ }^{\circ} \mathrm{C}$, while the low viscosity can
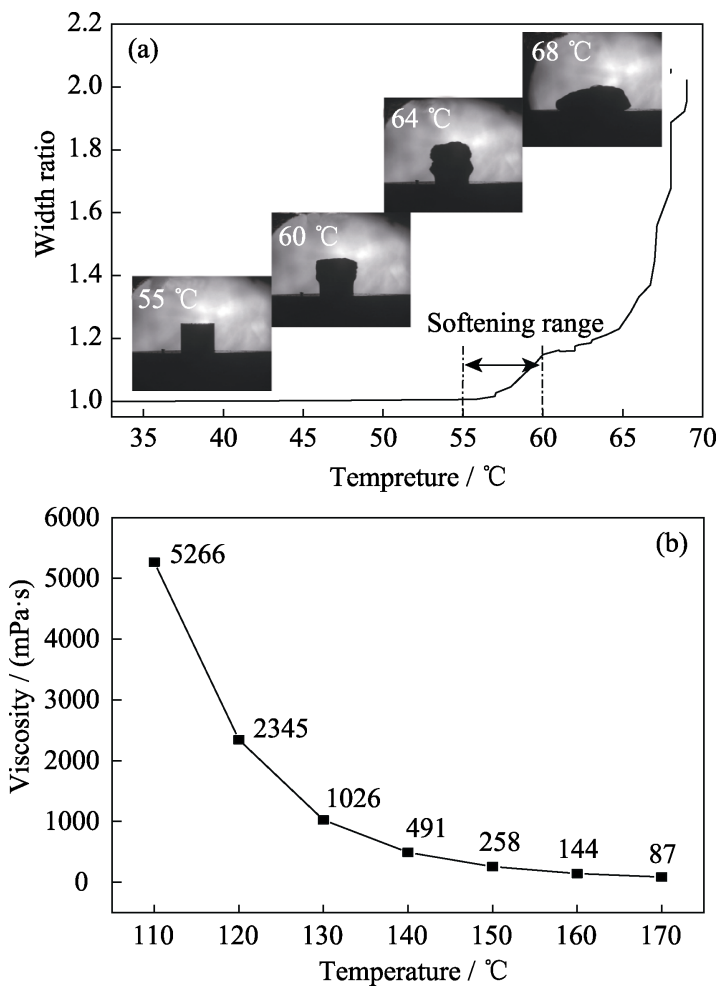

Fig. 3 (a) Change of geometric size of MK resin as a function of temperature; (b) Temperature dependence of the viscosity of MK resin lead to waste of precursor during the pyrolysis. To lower the curing temperature, CLA was applied as crosslinking agent considering the cross-linkable hydroxy and ethoxy groups.

CLA of various contents $(1 \mathrm{wt} \%, 0.5 \mathrm{wt} \%, 0.1 \mathrm{wt} \%$, $0.05 \mathrm{wt} \%$, and $0.01 \mathrm{wt} \%$ ) were added into MK resin to pick out the most suitable ratio. The optical photographs of MK resin with different contents of CLA heated at $160{ }^{\circ} \mathrm{C}$ are shown in Fig. 4, and the weight losses are also labeled. It can be observed that when no CLA was added, MK resin kept in the liquid state even after being heated at $160{ }^{\circ} \mathrm{C}$ for $12 \mathrm{~h}$ and the weight loss is only $0.67 \mathrm{wt} \%$. With the addition of CLA, MK resin can convert into solid state and the weight loss increased, which meant CLA could effectively promote the cross-linking of MK resin. When the content of CLA was higher than $0.1 \mathrm{wt} \%$, MK resin can get cross-linked within $30 \mathrm{~min}$. When $1 \mathrm{wt} \%$ CLA was added, the cross-linking time was as short as $5 \mathrm{~min}$ and the weight loss increased to $3.32 \mathrm{wt} \%$. When the content of CLA decreased to $0.05 \mathrm{wt} \%$ and $0.01 \mathrm{wt} \%$, the cross-linking time increased to about 1 and $3 \mathrm{~h}$, respectively. It can also be observed that when more than $0.05 \mathrm{wt} \%$ CLA was added, the crosslinked precursor presented a porous structure, which may be caused by escaping of generated gases during the cross-linking.

Rheological parameters such as storage modulus $\left(G^{\prime}\right)$ and loss modulus $\left(G^{\prime \prime}\right)$ were employed to further evaluate the curing behavior of MK resin. For the sake of convenience, MK resin with $0.05 \mathrm{wt} \%$ CLA was selected for rheological test. As shown in Fig. 5, storage moduli and loss moduli kept constant at the beginning of the test and then increased slowly until $1000 \mathrm{~s}$. Two moduli increased sharply after $1000 \mathrm{~s}$, and there was an intersection point of $G^{\prime}$ and $G^{\prime \prime}$ at about $1970 \mathrm{~s}$. After the intersection point, the $G^{\prime}$ exceeded $G^{\prime \prime}$, which indicated that the elastic deformation of MK resin was dominant rather than viscous deformation of materials. Furthermore, the polymer began to transform into elastomer. The gel point of MK resin, on which the polymer begins to crosslink, can be determined by the intersection point of $G^{\prime}$ and $G^{\prime \prime[19]}$. It can be concluded that MK resin with $0.05 \mathrm{wt} \%$ CLA began to crosslink after being treated at $160{ }^{\circ} \mathrm{C}$ for $0.5 \mathrm{~h}$, which is in consistent with the phenomenon referred above.

To investigate the curing mechanism, FT-IR spectroscopy of the as-received MK resin (without cross-linking) and MK resin with $0.01 \mathrm{wt} \%$ CLA cured at $160{ }^{\circ} \mathrm{C}$ were tested (Fig. 6). The spectrum of MK resin shows absorption bands at $v=765,1275 \mathrm{~cm}^{-1}\left(\mathrm{Si}-\mathrm{CH}_{3}\right), v=2913,2975 \mathrm{~cm}^{-1}$ $(\mathrm{C}-\mathrm{H}), v=1618,3437 \mathrm{~cm}^{-1}(\mathrm{Si}-\mathrm{OH}), v=1023 \mathrm{~cm}^{-1}$ $(\mathrm{Si}-\mathrm{O}-\mathrm{C})$ and $v=1111 \mathrm{~cm}^{-1}(\mathrm{Si}-\mathrm{O}-\mathrm{Si})$, as previously 

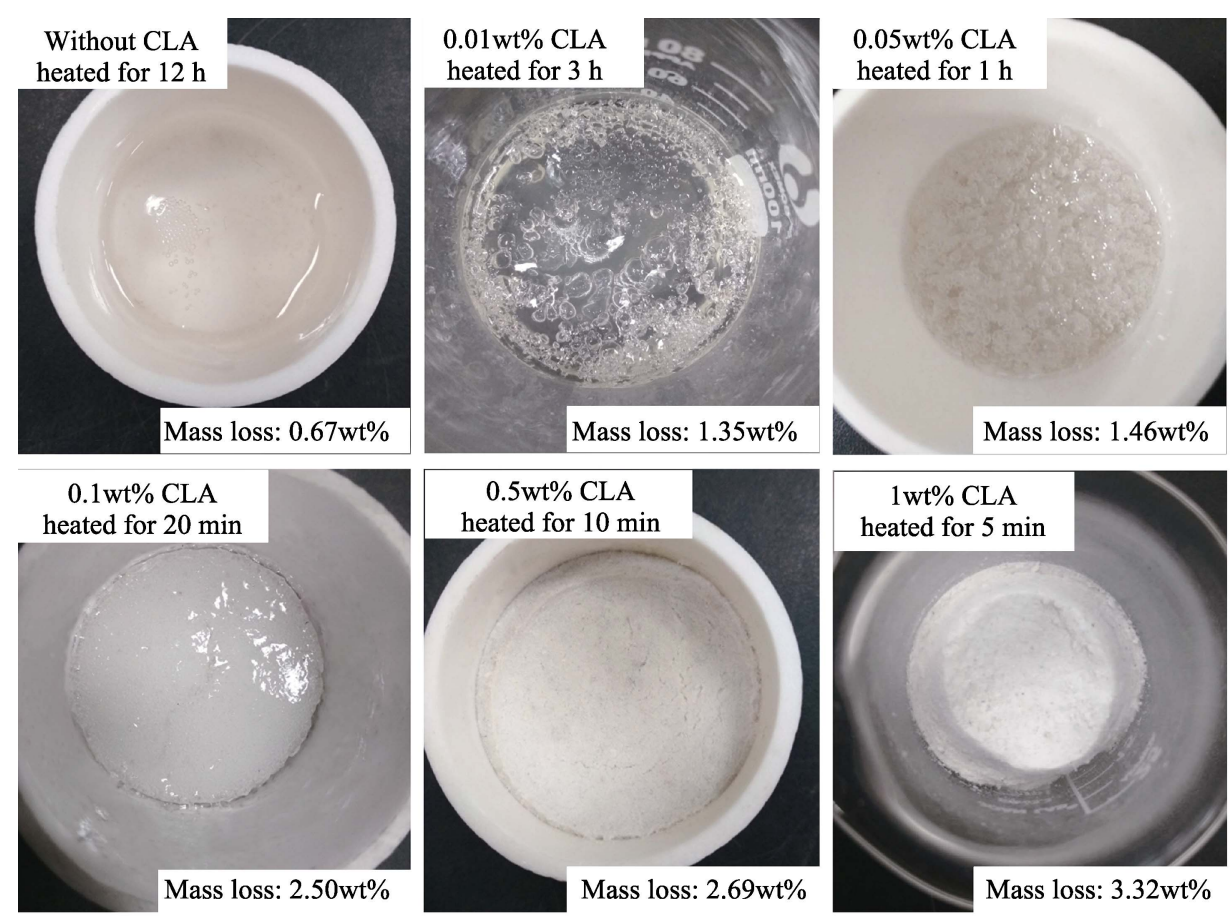

Fig. 4 Optical photographs of MK resin with different contents of CLA after heat treatment at $160{ }^{\circ} \mathrm{C}$

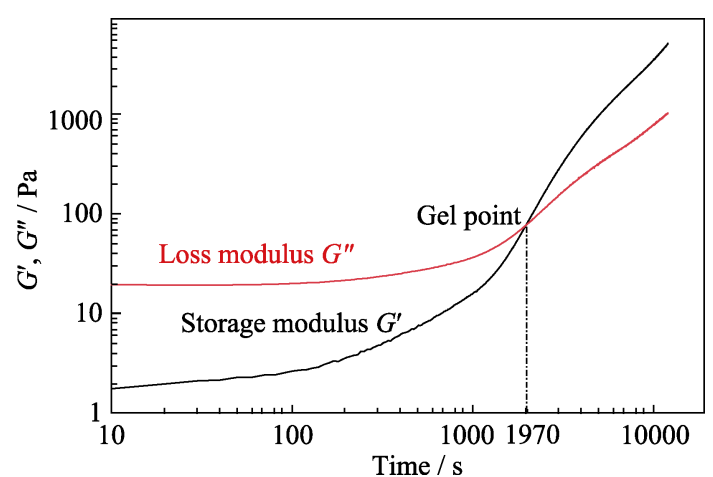

Fig. 5 Storage moduli and loss moduli versus curing time for MK resin with $0.05 \mathrm{wt} \%$ CLA at $160{ }^{\circ} \mathrm{C}$

reported $^{[16,20-23]}$. As the curing time increases, the intensity of absorption bands assigned to $\mathrm{Si}-\mathrm{O}-\mathrm{C}$ and $\mathrm{Si}-\mathrm{O}-\mathrm{Si}$ slightly increases. What's more, the intensities of $\mathrm{Si}-\mathrm{O}-\mathrm{Si}$ and $\mathrm{Si}-\mathrm{O}-\mathrm{C}$ increases with curing time, indicating that the network of $\mathrm{Si}-\mathrm{O}-\mathrm{Si}$ was gradually formed. It can be concluded that condensation reactions of $\mathrm{Si}-\mathrm{OH}$ with $\mathrm{Si}-\mathrm{OH}, \mathrm{Si}-\mathrm{OEt}$ as well as with $\mathrm{RSO}_{2}-\mathrm{OH}$ groups with the aids of CLA are main reactions involved during cross-linking.

FT-IR spectroscopy of the cured MK resins with different contents of CLA were also tested as shown in Fig. 7. There is no obvious difference in their IR spectra except for the absorption bands for $\mathrm{Si}-\mathrm{O}$ (at 1023 and $1111 \mathrm{~cm}^{-1}$ ) and $-\mathrm{OH}$ (at 1618 and $3437 \mathrm{~cm}^{-1}$ ). As the CLA content increases, the intensity ratio of $\mathrm{Si}-\mathrm{O}-\mathrm{Si}$ and $\mathrm{Si}-\mathrm{O}-\mathrm{C}$ absorption increases, which reveals that CLA affects curing rate and cross-linking degree of MK resin. Excessively rapid cross-linking rate results in generation (a)
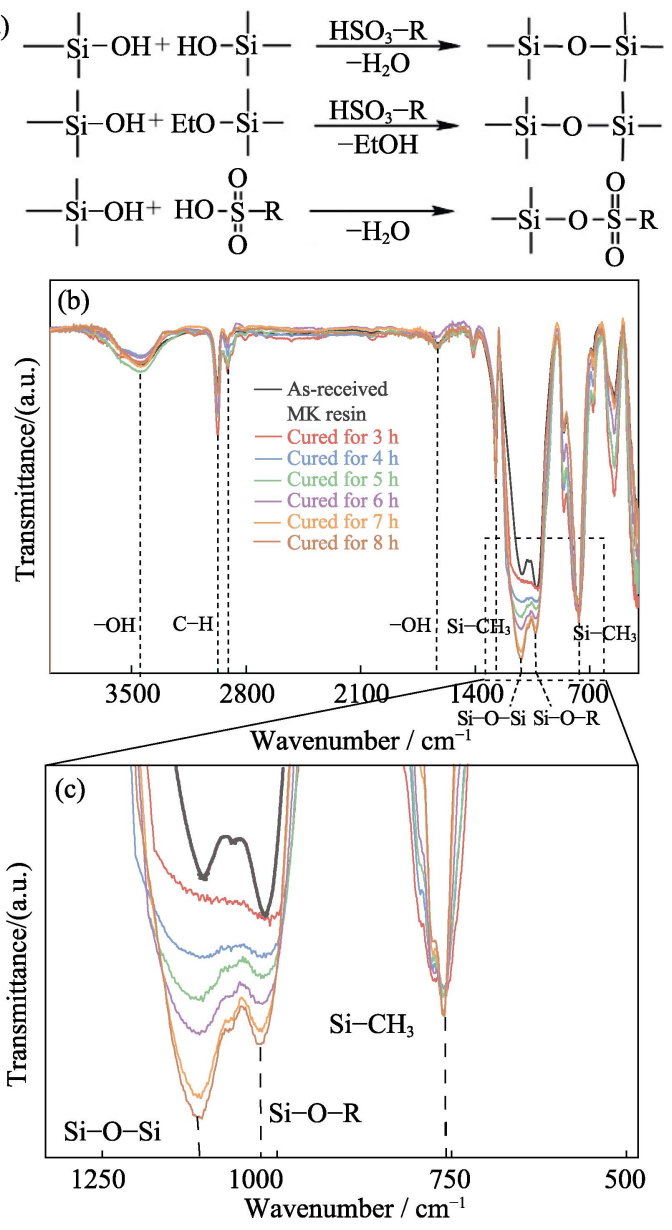

Fig. 6 (a) Cross-linking reactions during the curing process; (b) FT-IR spectra of as-obtained MK resin without curing and MK resin with $0.01 \mathrm{wt} \%$ CLA after curing at $160{ }^{\circ} \mathrm{C}$ for different time; (c) details in enlarged view of wavenumber in the range from $1250 \mathrm{~cm}^{-1}$ to $500 \mathrm{~cm}^{-1}$ 


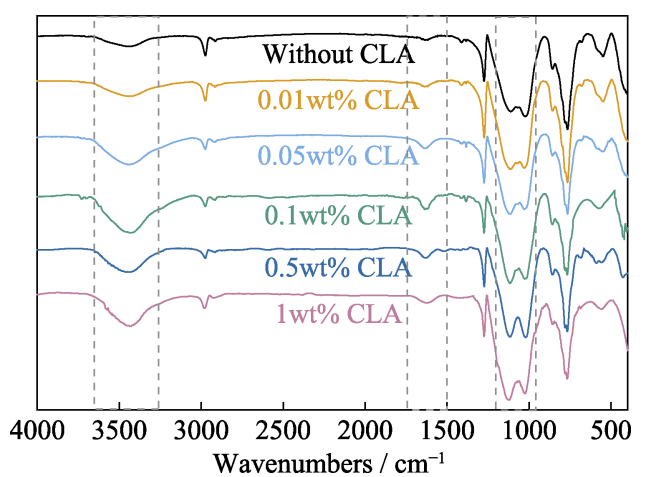

Fig. 7 FT-IR spectra of MK resin with various contents of CLA after being treated at $160{ }^{\circ} \mathrm{C}$ for $8 \mathrm{~h}$

of a mass of small molecules such as ethanol and $\mathrm{H}_{2} \mathrm{O}$ which fails to volatilize before $\mathrm{Si}-\mathrm{O}-\mathrm{Si}$ network is formed, and is then absorbed in porous structure of the cured MK resin. Consequently, the intensity of $-\mathrm{OH}$ bands show a remarkable increase.

TG-DTA curves of MK resin without CLA from $100{ }^{\circ} \mathrm{C}$ to $1000{ }^{\circ} \mathrm{C}$ were shown in Fig. 8. The ceramic yield is as high as $88 \mathrm{wt} \%$ after pyrolyzation at $1000{ }^{\circ} \mathrm{C}$. The weight loss mainly occurred in two temperature ranges. A weight loss of about $4.91 \mathrm{wt} \%$ occurred at temperatures ranging from $170{ }^{\circ} \mathrm{C}$ to $350{ }^{\circ} \mathrm{C}$, which may be ascribed to the vaporization of $\mathrm{H}_{2} \mathrm{O}, n$-propanol, ethanol and POSS during the cross-linking process ${ }^{[16,23-26]}$. A further weight loss of about $\sim 6.09 \mathrm{wt} \%$ occurs between 350 and $900{ }^{\circ} \mathrm{C}$, which may be resulted from breakage/ rearrangement of molecular chains and release of a large number of small molecular gas, such as $\mathrm{H}_{2}, \mathrm{H}_{2} \mathrm{O}$ and propane, etc. ${ }^{[15,22]}$. Table 1 shows the ceramic yields of $\mathrm{MK}$ resin with different CLA contents pyrolized at $1000{ }^{\circ} \mathrm{C}$ in Ar atmosphere and the chemical compositions of the pyrolysates in the formation of $x \mathrm{SiO}_{2} \cdot y \mathrm{SiC} \cdot z \mathrm{C}$. The ceramic yields of MK resin with different contents of CLA ranges from $82.9 \mathrm{wt} \%$ to $85.6 \mathrm{wt} \%$, which means that the effect of CLA on the ceramic yield is negligible. It is indicated that free carbon is less than $3 \mathrm{wt} \%$ in pyrolysates.

\subsection{Microstructures and mechanical proper- ties of $\mathrm{C} / \mathrm{SiOC}$ composites}

Based on the above-mentioned cross-linking and

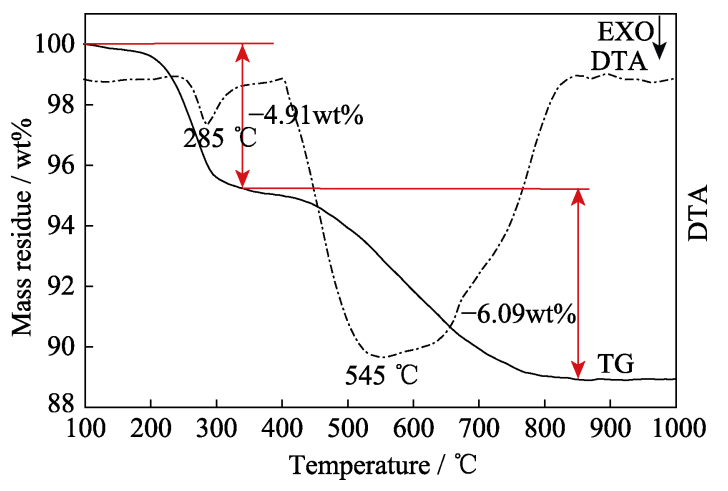

Fig. 8 TGA-DTA curves of the decomposition behavior for MK resin

pyrolysis behavior of MK resin with different CLA contents, it is found that the MK resin with $0.01 \mathrm{wt} \%$ of CLA is a suitable matrix precursor for the fabrication of $\mathrm{C} / \mathrm{SiOC}$ composites, which can guarantee enough time for the molten precursor to be infiltrated into the fiber preform. During the PIP process, the precursor was first cross-linked at $160{ }^{\circ} \mathrm{C}$ for $4 \mathrm{~h}$ before pyrolysis.

Fig. 9 shows the density and the open porosity of $\mathrm{C} / \mathrm{SiOC}$ composites as a function of PIP cycles. It is obvious that the density increases with the increase of PIP cycles, and the open porosity decreases. As a result of high ceramic yield of precursor as well as eliminating effect of solvent, the high efficiency in modified PIP was realized in comparation with the conventional ones. Remarkably, the open porosity of $\mathrm{M}-\mathrm{C} / \mathrm{SiOC}$ composites $(6.2 \%)$ is much lower than that of $\mathrm{C}-\mathrm{C} / \mathrm{SiOC}$ composites (17.4\%) after 8 cycles. After the first cycle, the density of $\mathrm{M}-\mathrm{C} / \mathrm{SiOC}$ composites increased from $0.6 \mathrm{~g} / \mathrm{cm}^{3}$ to $1.14 \mathrm{~g} / \mathrm{cm}^{3}$. Compared with the $\mathrm{C}-\mathrm{C} / \mathrm{SiOC}$ composites, the final $\mathrm{M}-\mathrm{C} / \mathrm{SiOC}$ composite possessed relatively high density of about $1.81 \mathrm{~g} / \mathrm{cm}^{3}$ after the eighth cycle. Similarly, the density of $\mathrm{C} / \mathrm{SiOC}$ composites fabricated via the modified PIP process in this work is increased by about $10 \%$ in comparation with the results of $1.64 \mathrm{~g} / \mathrm{cm}^{3}$ in the reported literature ${ }^{[27]}$.

Fig. 10 shows the cross-sectional microstructures of the final $\mathrm{C} / \mathrm{SiOC}$ composites fabricated by two different $\mathrm{PIP}$ processes. Compared with the $\mathrm{C}-\mathrm{C} / \mathrm{SiOC}$ composites

Table 1 The ceramic yield and the element composition for MK resin with different CLA contents pyrolized at $1000{ }^{\circ} \mathrm{C}$

\begin{tabular}{cccccccc}
\hline CLA content/wt $\%$ & Ceramic yield/wt $\%$ & $\mathrm{Si} / \mathrm{wt} \%$ & $\mathrm{O} / \mathrm{wt} \%$ & $\mathrm{C} / \mathrm{wt} \%$ & Empirical formula & Free $\mathrm{C} / \mathrm{wt} \%$ \\
\hline 0 & 83.7 & 53.17 & 33.96 & 12.87 & $0.56 \mathrm{SiO}_{2} \cdot 0.44 \mathrm{SiC}+0.12 \mathrm{C}_{\text {free }}$ & 2.82 \\
0.01 & 85.1 & 53.13 & 33.89 & 12.98 & $0.56 \mathrm{SiO}_{2} \cdot 0.44 \mathrm{SiC}+0.13 \mathrm{C}_{\text {free }}$ & 2.92 \\
0.05 & 85.7 & 53.89 & 33.05 & 13.06 & $0.54 \mathrm{SiO}_{2} \cdot 0.46 \mathrm{SiC}+0.10 \mathrm{C}_{\text {free }}$ & 2.36 \\
0.1 & 84.7 & 54.46 & 33.15 & 13.39 & $0.54 \mathrm{SiO}_{2} \cdot 0.46 \mathrm{SiC}+0.13 \mathrm{C}_{\text {free }}$ & 2.91 & 2.09 \\
0.5 & 84.1 & 54.74 & 31.54 & 13.72 & $0.50 \mathrm{SiO}_{2} \cdot 0.50 \mathrm{SiC}+0.09 \mathrm{C}_{\text {free }}$ & 2.70 \\
1 & 82.9 & 53.86 & 32.57 & 13.57 & $0.53 \mathrm{SiO}_{2} \cdot 0.47 \mathrm{SiC}+0.12 \mathrm{C}_{\text {free }}$ & 2.70 \\
\hline
\end{tabular}




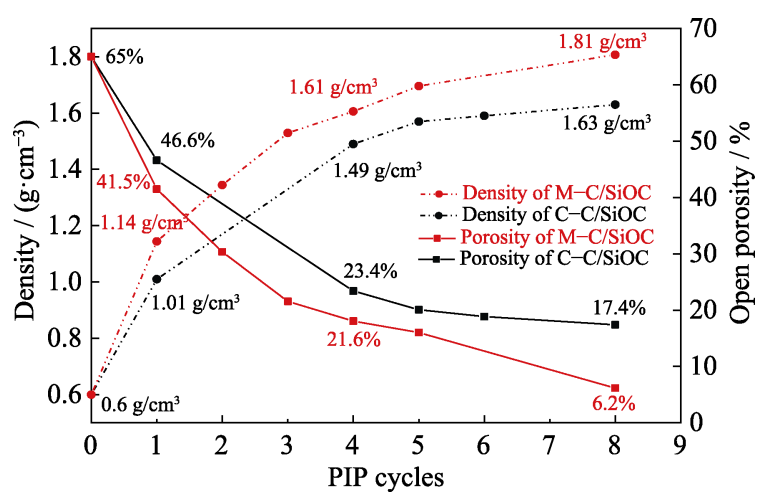

Fig. 9 Density and open porosity variation of $\mathrm{C} / \mathrm{SiOC}$ composites during the PIP process
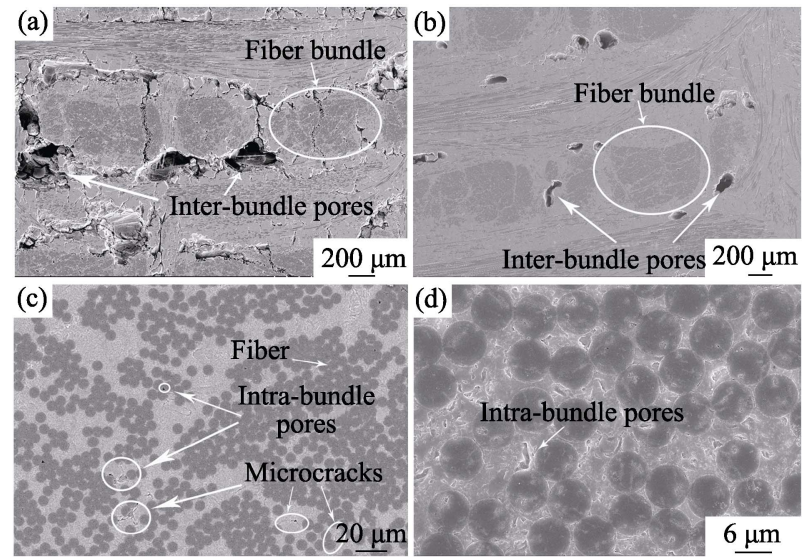

Fig. 10 SEM images of the polished cross sections of (a) $\mathrm{C}-\mathrm{C} / \mathrm{SiOC}$ composites; (b-d) M-C/SiOC composites

(Fig. 10(a)), the inter-bundle pores in $\mathrm{M}-\mathrm{C} / \mathrm{SiOC}$ composites is obviously much less (Fig. 10(b)). Although some pores can still be found in the matrices, the final $\mathrm{M}-\mathrm{C} / \mathrm{SiOC}$ composites are highly dense in general. When the preforms were infiltrated via the modified PIP process, the precursors with moderate viscosity can fill in almost all pores and turn into solid state during the cross-link process. The existence of sevaral micro-pores and microcracks in matrices (Fig.10(b-d)) can be attributed to generation of close pores resulted from porous precursor pyrolysates during the precious PIP cycles. Therefore, the precursor can't reach anymore in the latter infiltration process.

The three-point-bending test shows that the M-C/ $\mathrm{SiOC}$ composites possess a relatively higher bending strength of (312 \pm 25$) \mathrm{MPa}$ than the $\mathrm{C}-\mathrm{C} / \mathrm{SiOC}$ composites with a bending strength of $(211 \pm 7) \mathrm{MPa}$. The M-C/SiOC composites also show superiority in mechanical properties as compared to the $\mathrm{C} / \mathrm{SiOC}$ composites prepared by conventional PIP process with other polysiloxane precursors reported $\left(217^{[28]}, 247^{[29]}\right.$ and $\left.265^{[1]}\right)$. The $\mathrm{M}-\mathrm{C} / \mathrm{SiOC}$ composites show a typical non-brittle fracture behavior, which can be concluded from the bending stress-strain curves of three-point bending test as shown in Fig. 11. The stress-strain curve of the M-C/SiOC

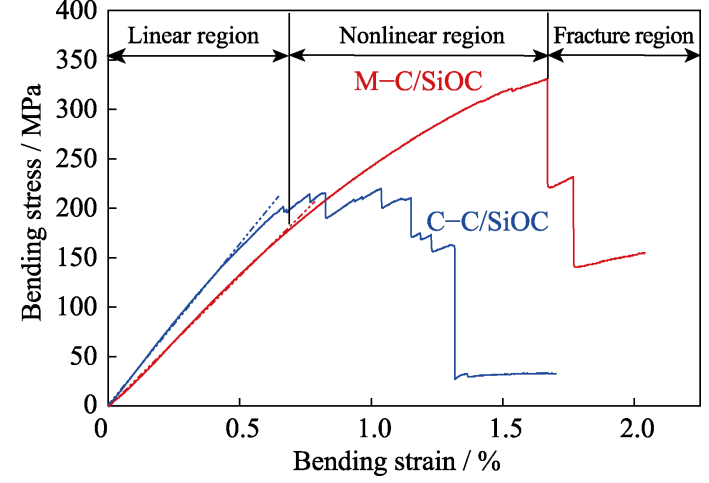

Fig. 11 Typical bending stress vs. strain curve for the C/SiOC composites

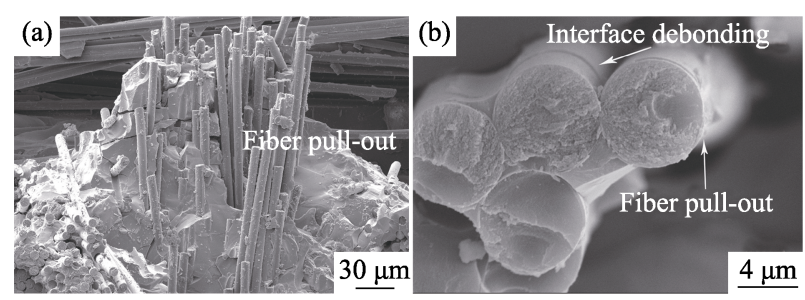

Fig. 12 SEM micrographs of the fracture surfaces of M-C/ SiOC composites

composites can be divided into three regions, namely, linear region, non-linear region and fracture region. In the non-linear region, micro-cracks generation and propagation as well as the interfacial debonding are responsible for the pseudo-plastic deformation behavior ${ }^{[30]}$. Once the stress reaching to the maximum as observed in the fracture region, the stress drops abruptly. Then the stress show a step-like decrease, which may be ascribed to the layer-fiber-distribution characteristics of the preforms. At the beginning of three-point-bending test, fibers on the underside layer have the largest deformation. When fibers at this layer was destroyed, the second layer of fibers momentarily bear the load, therefore the imposed load dropped abruptly, then slightly increased again. Meanwhile, the C-C/ SiOC composites show a narrower non-linear region, leading to the worse bending strength.

Fig. 12 shows the microstructure of fracture surfaces of the M-C/SiOC composites. Pulled-out fibers can be observed in the SiOC matrix. As the deposited PyC interphase ensures the weak bonding between matrix and fiber, cracks can propagate either along the matrix-PyC interface or along PyC-fiber interphase. Therefore, the de-bonding phenomenon can be observed on the surface of the pulled-out fibers.

\section{Conclusion}

Based on a modified highly-efficient PIP process using molten $\mathrm{MK}$ resin, $\mathrm{C} / \mathrm{SiOC}$ composites with a density of $1.81 \mathrm{~g} / \mathrm{cm}^{3}$ was fabricated by only 8 cycles of PIP. 
When MK resin with $0.01 w t \%$ CLA was firstly crosslinked at $160{ }^{\circ} \mathrm{C}$ for $4 \mathrm{~h}$, precursor can tranform into solid state and fill in both inter-bundle pores and intrabundle pores, therefore only very small amount of micropores can be found in the composites. The as-fabricated $\mathrm{C} / \mathrm{SiOC}$ composites possess a relatively high bending strength of $(312 \pm 25) \mathrm{MPa}$ and show an obvious nonbrittle fracture behavior.

\section{References:}

[1] MA Q S, CHEN Z H, ZHENG W W, et al. Effects of pyrolysis processes on microstructure and mechanical properties of $\mathrm{C}_{\mathrm{f}} / \mathrm{Si}-\mathrm{O}-\mathrm{C}$ composites fabricated by preceramic polymer pyrolysis. Mater. Sci. Eng. A, 2003, 352: 212-216.

[2] PAPAKONSTANTINOU C G, BALAgURU P, LYON R E. Comparative study of high temperature composites. Composites Part B, 2001, 32: 637-649.

[3] NASLAIN R. Design, preparation and properties of non-oxide CMCs for application in engines and nuclear reactors: an overview. Compos. Sci. Technol., 2004, 64: 155-170.

[4] KIM S Y, HAN I S, WOO SK, et al. Wear-mechanical properties of filler-added liquid silicon infiltration $\mathrm{C} / \mathrm{C}-\mathrm{SiC}$ composites. $M a$ terials and Design, 2013, 44: 107-113.

[5] DUTTA S. Fracture toughness and reliability in high-temperature structural ceramics and composites: prospects and challenges for the 21st century. Bull. Mater. Sci., 2001, 24: 117-120.

[6] ZHONG H, WANG Z, ZHOU H J, et al. Properties and microstructure evolution of $\mathrm{C}_{\mathrm{f}} / \mathrm{SiC}$ composites fabricated by polymer impregnation and pyrolysis (PIP) with liquid polycarbosilane. $\mathrm{Ce}$ ram. Int., 2 2017, 243: 7387-7392.

[7] SAHA A, RAJ R. A model for the nanodomains in polymerderived SiCO. J. Am. Ceram. Soc., 2006, 89: 2188-2195.

[8] PANTANO C, SINGH A, ZHANG H. Silicon oxycarbide glasses. J. Sol-Gel Sci. Technol., 1999, 14(1): 7-25.

[9] LIU H T, CHENG H F, WANG J, et al. Effects of the fiber surface characteristics on the interfacial microstructure and mechanical properties of the $\mathrm{KD} \mathrm{SiC}$ fiber reinforced $\mathrm{SiC}$ matrix composites. Mater. Sci. Eng. A, 2009, 525(1/2): 121-127.

[10] WANG S, CHEN Z H, MA Q S, et al. Effect of fiber surface state on mechanical properties of $\mathrm{C}_{\mathrm{f}} / \mathrm{Si}-\mathrm{O}-\mathrm{C}$ composites. Mater. Sci. Eng. A, 2005, 407: 245-249.

[11] MA Q S, CHEN Z H, ZHENG W W, et al. Curing and pyrolysis of polysiloxane/divinylbenzene and its derived carbon fiber reinforced Si-O-C composites. J. Mater. Sci., 2005, 40: 361-365.

[12] XU T H, MA Q S, CHEN Z H. Mechanical property and microstructure evolutions of $\mathrm{C}_{\mathrm{f}} / \mathrm{SiOC}$ composites with increasing annealing temperature in reduced pressure environment. Ceram. Int., 2012, 38: 605-611.

[13] KASPARA J, GRACZYK Z M, CHOUDHURY S, et al. Impact of the electrical conductivity on the lithium capacity of polymerderived silicon oxycarbide (SiOC) ceramics. Electrochimica Acta, 2016, 216: 196-202.

[14] IONESCU E, BALAN C, KLEEBE H J, et al. High-temperature creep behavior of SiOC glass-ceramics: influence of network carbon versus segregated carbon. J. Am. Ceram. Soc., 2014, 97: 3935-3942.

[15] MOSYAN C, RIEDEL R, HARSHE R, et al. Mechanical characterization of a polysiloxane-derived SiOC glass. J. Eur. Ceram. Soc., 2007, 27: 397-403.

[16] IONESCU E, LINCK C, FASEL C, et al. Polymer-derived SiOC/ $\mathrm{ZrO}_{2}$ ceramic nanocomposites with excellent high-temperature stability. J. Am. Ceram. Soc., 2010, 93: 241-250.

[17] KASPAR J, TERZIOGLU C, IONESCU E, et al. Stable SiOC/Sn nanocomposite anodes for lithium-ion batteries with outstanding cycling stability. Adv. Funct. Mater, 2014, 24: 4097-4104.

[18] SUO J, ZHENG W, XIAO J Y, et al. Optimized condition for precursor infiltration method. Aerosp. Mater. Technol., 2002, 2: 29-32.

[19] GARCIA M V, GUDE M R, URENA A. Understanding the curing kinetics and rheological behaviour of a new benzoxazine resin for carbon fibre composites. React. Funct. Polym., 2018, 129: 103-110.

[20] IONESCU E, PAOENDORF B, KLEEBE H J, et al. Polymerderived silicon oxycarbide/hafnia ceramic nanocomposites. Part I: phase and microstructure evolution during the ceramization process. J. Am. Ceram. Soc., 2010, 93: 1774-1782.

[21] IONESCU E, PAOENDORF B, KLEEBE H J, et al. Polymerderived silicon oxycarbide/hafnia ceramic nanocomposites. Part II: stability toward decomposition and microstructure evolution at T1000 degrees C. J. Am. Ceram. Soc., 2010, 93: 1783-1789.

[22] HARSHE R, BALAN C, RIEDEL R. Amorphous Si(Al)OC ceramic from polysiloxanes: bulk ceramic processing, crystallization behavior and applications. J. Eur. Ceram. Soc., 2004, 24: 3471-3482.

[23] LIU C, MENG X Y, ZHANG X H, et al. High temperature structure evolution of macroporous $\mathrm{SiOC}$ ceramics prepared by a Sol-Gel method. Ceram. Int., 2015, 41: 11091-11096.

[24] PAN J M, YAN X H, CHENG X N, et al. In situ synthesis and electrical properties of porous SiOC ceramics decorated with $\mathrm{SiC}$ nanowires. Ceram. Int., 2016, 42: 12345-12351.

[25] DUAN X Y, YIN X W, LUO C J, et al. Microwave-absorption properties of SiOC ceramics derived from novel hyperbranched ferrocene-containing polysiloxane. J. Eur. Ceram. Soc., 2017, 37: 2021-2030.

[26] MA Q S, CHEN Z H, ZHEN W W, et al. Processing and characterization of three-dimensional carbon fiber reinforced Si-O-C composites via precursor pyrolysis. Mater. Sci. Eng. A, 2003, 352: 212-216.

[27] XU T H, MA Q S, CHEN Z H. High-temperature behavior of $\mathrm{C}_{\mathrm{f}} / \mathrm{SiOC}$ composites in inert atmosphere. Mater. Sci. Eng. A, 2011, 530: 266-270.

[28] JIAN K, CHEN Z H, MA Q S, et al. Processing and properties of $2 \mathrm{D} \mathrm{C}_{\mathrm{f}} / \mathrm{SiOC}$ composites using silicone resin. Key Engineering Materials, 2007, 336-338: 1251-1253.

[29] XU T H, CHEN Z H, MA Q S. Effect of the first cycle of precursor solution infiltration on the properties of $3 \mathrm{D}-\mathrm{C}_{\mathrm{f}} / \mathrm{Si}-\mathrm{O}-\mathrm{C}$ via PIP. Rare Metal Materials and Engineering, 2008, 37: 600-603.

[30] DING Q, NI D W, WANG Z, et al. 3D $\mathrm{C}_{\mathrm{f} /} \mathrm{SiBCN}$ composites prepared by an improved polymer infiltration and pyrolysis. $J$. $A d v$. Ceram., 2018, 7: 266-275. 


\title{
基于固体聚硅氧烷的前驱体浸渍裂解法(PIP)制备 $\mathrm{C} / \mathrm{SiOC}$ 复合材料及其微结构与力学性能研究
}

\author{
吴青青 ${ }^{1,2}$, 王 震 ${ }^{1,3}$, 丁 奇 ${ }^{1,2,4}$, 倪德伟 ${ }^{1,3}$, 阚艳梅 ${ }^{1,3}$, 董绍明 ${ }^{1,5}$
}

(1. 中国科学院 上海硅酸盐研究所, 高性能陶瓷和超微结构国家重点实验室, 上海 200050; 2. 中国科学院大学, 北京 100049 ; 3. 中国科学院 上海硅酸盐研究所, 结构陶瓷与复合材料工程研究中心, 上海 $200050 ; 4$. 上海科技 大学, 上海 201210; 5. 中国科学院大学 材料与光电研究中心, 北京 100049)

摘 要: 以熔融的 MK 树脂(聚甲基倍半硅氧烷)为前驱体, 采用改进的前驱体浸渍裂解法(PIP)制备了致密的 C/SiOC 复合材料。为了降低 MK 树脂的固化温度, 选择有机磺酸作为交联剂, 并采用红外光谱分析仪(FT-IR)和热重分析差热分析仪(TG-DTA)研究了 MK 树脂的固化机理和陶瓷化行为。研究表明: MK 树脂的陶瓷产率高达 $85 \mathrm{wt} \%$, 其裂 解得到的 SiOC 陶瓷自由碳含量低于 $3 \mathrm{wt} \%$, 有利于提高陶瓷的高温稳定性。经过 8 次 PIP 制备的 C/SiOC 复合材料 的密度可达 $1.82 \mathrm{~g} / \mathrm{cm}^{3}$ 。对得到的 $\mathrm{C} / \mathrm{SiOC}$ 复合材料进行三点弯曲测试, 其弯曲强度为(312 \pm 25$) \mathrm{MPa}$, 表现出明显的 非脆性断裂行为。

关 键 词: $\mathrm{C} / \mathrm{SiOC}$ 复合材料; 高效 PIP; 微观结构; 交联机理

中图分类号: TQ174 文献标识码: A 